\title{
Cambial Variants in the Family Menispermaceae in Taiwan
}

\author{
Sheng-Zehn Yang*, Po-Hao Chen \\ National Pingtung University of Science and Technology, Taiwan \\ Email: *yangsz@mail.npust.edu.tw, 126571583@yahoo.com.tw
}

Received 21 February 2016; accepted 22 April 2016; published 25 April 2016

Copyright (C) 2016 by authors and Scientific Research Publishing Inc.

This work is licensed under the Creative Commons Attribution International License (CC BY). http://creativecommons.org/licenses/by/4.0/

(c) (i) Open Access

\begin{abstract}
Anatomical data regarding the climbing modes and cambial variants of the stem transverse section in the Menispermaceae in Taiwan are lacking. Here, we examined the climbing modes and anomalous structure of climber stems in this family. Reviewing the previous reports of cambial variants in angiosperm liana families, a list of angiosperm liana families processing specified types of cambial variants and the terms based on description for the transverse section of a stem were provided. The results show that Cocculus laurifolius DC. is a shrub, Stephania cephalantha Hayata and Stephania longa Lour. are vines, and the remaining 13 species are lianas. In all species, the climbing mode was twining and dextrorse stems. The anomalous structure of the stem comprised successive cambia in Cocculus laurifolius, a combination of xylem in plates and dissected xylem in Cocculus orbiculatus (L.) DC., and xylem in plates in the remaining 14 species. In the genus Cyclea, parenchyma proliferation from the secondary xylem resulted in the development of 1 3 linear lobes in each collateral vascular bundle. The vessel diameter of $C$. laurifolius is $<50 \mu \mathrm{m}$ which is the smallest size due to shrub in its life stage. $C$. orbiculatus had the longest collateral vascular bundles, longest rays and widest rays. Cyclea ochiaiana (Yamam.) S. F. Huang \& T. C. Huang had the widest collateral vascular bundles. Sinomenium acutum (Thunb.) Rehder \& E. H. Wilson had the highest vessel density. Tinospora crispa (L.) Hook. F. et Thoms develops blunt tubercles on the epidermis and Stephania tetrandra S. Moore bears conspicuous phellem layer. Those findings, such as the climbing mode, the features of parenchyma proliferation, the features of collateral vascular bundles (number, width, length), dimorphic vessels, and size and density of vessels, highlight new anatomical characteristics for species identification in the Menispermaceae in Taiwan.
\end{abstract}

\section{Keywords}

Anatomical Characteristics, Cambial Variants, Menispermaceae, Stem Transverse Section, Taiwan

\footnotetext{
${ }^{*}$ Corresponding author.
} 


\section{Introduction}

The family Menispermaceae is moderately supported as a sister group of the families Ranunculaceae and Berberidaceae. There are approximately 70 genera and 450 species distributed in tropical or subtropical lowland regions, mostly dioecious climbing plants, rarely trees, shrubs, or herbs in this family [1] [2]. Members of this family Menispermaceae contain large amounts of alkaloids and terpenoids [2], and they are therefore commonly used in traditional medicine [3]. Six genera and 13 taxa of this family have been identified in the Flora of Taiwan [4].

The roots of climbers are generally buried in the soil, whereas the stems rise by various climbing mechanisms and are dependent on external supports [5]. Climbing is divided into two stages-the climbing stage and the autologous support stage. The climbing stage involves the growth and development of a special internal structure of the liana stem, which is either variant or anomalous [6]. The morphological variation of liana stems is mainly associated with the geometry of the phloem and xylem structure, and the irregular shapes are classified into several types [6]-[12].

Most vascular plants have a single vascular cambium, which originates from an initial fusiform cell and an initial ray cell. The amount of secondary xylem produced towards the inside of the stem exceeds the amount of secondary phloem produced towards the outside of the stem, and all the secondary xylem and secondary phloem grow along the peripheral organs. Cambial variants are the most common features of the secondary growth mode of vascular plants, and they are more common in lianas than in trees or shrubs [9] [11] [13]. In the absence of leaves and flowers, cambial variation provides a unique means of classification, and hence it can be used to identify many families and genera [10]. In particular, members of the family Menispermaceae develop successive cambia with wide rays [1] [14] [15].

The basic elements of a stem are the epidermis, periderm, cortex, and central column (vascular stele) [16]. The vascular stele consists of pith, vascular bundles, and the pericycle (phloem fibers). The vascular bundle is composed of the xylem, phloem, and fascicular cambium. A vascular bundle that contains phloem on only one side of the xylem, usually the abaxial side, is termed a collateral vascular bundle [17] [18]. Pericycles are found in the region of tissue between the primary vascular tissues and the cortex. The fascicular cambium typically produces secondary xylem and secondary phloem, whereas the interfascicular cambium produces only ray-like parenchyma tissues [18].

However, data regarding the patterns and complex characteristics of stem transverse sections in this family in Taiwan are lacking. In the present study, we examined the climbing modes and stem transverse sections in sixteen different species belonging to the family Menispermaceae in Taiwan. Owing to very diverse cambial variants, the present study attempts to address by 1) carefully revising the various descriptors used and providing detailed photographs of features, 2) developing a key based on morphological characters of stem transverse section for identification of species in Taiwan. Our objective was to facilitate the identification of irregular cambial activity.

\section{Materials and Methods}

\subsection{Research Materials}

During 2012 to 2015, we collected fresh stem specimens of sixteen species in seven genera, representing all species of the family Menispermaceae in Taiwan (species list see Appendix 1). Among them, Cissampelos pareira L. var. hirsuta (DC.) Forman is a newly recorded species and represents the first generic record of Cissampelos in Taiwan [19]. Cyclea ochiaiana (Yamam.) S. F. Huang \& T. C. Huang, Stephania merrillii Diels and Tinospora dentata Diels are endemic in Taiwan. T. crispa (L.) Hook. f. et Thoms. and T. sinensis (Lour.) Merr. are cultivated plants. All the collected specimens were deposited in the herbarium of the Provincial Pingtung Institute (PPI), Pingtung, Taiwan. The scientific names of the collected specimens were obtained from the Flora of Taiwan [4]. We identified the climbing mode in each of the investigated species following [5].

\subsection{Research Methods}

The collected plant stems of each species were of various sizes, and therefore we observed the similarities or differences in their stem cross-sections. All the fresh stems specimens were collected in diameter at breast height (DBH). The fresh materials were cut into pieces (length $\sim 5 \mathrm{~cm}$ ) and a flat cross-section of each stem was cut by 
cutter blade. After cutting the fresh stem surface as flat as possible, we immediately took pictures of the stem surface. Photographs of the stem cross-sections were taken using a Nikon D80 SLR digital camera (Lens AF Micro Nikkor $60 \mathrm{~mm}$ 1: 2.8D, made in Nikon Corporation, Tokyo, Japan), and qualitative and quantitative anatomical traits were determined using Image-J software. We measured the following parameters: stem diameter $(\mathrm{mm})$; pith diameter $(\mathrm{mm})$; number, length $(\mathrm{mm})$, and width $(\mathrm{mm})$ of the collateral vascular bundles; length $(\mathrm{mm})$ and width (mm) of the rays; width of the rays towards the periphery; mean number of vessels per xylem bundle; vessel density (number per $\mathrm{mm}^{2}$ ); and vessel diameter $(\mu \mathrm{m})$. In species in which the anomalous structure of stem was successive cambia, we measured these parameters in the first cambial layer for comparison [21]. The specimens were dried at $60^{\circ} \mathrm{C}$ in an oven for 4 - 5 days and were then stored at $-40^{\circ} \mathrm{C}$ for 3 - 4 days. Dried specimens were deposited in the herbarium of the PPI.

\subsection{Cambial Variants in Lianas}

According to the previous literature reports of cambial variants in angiosperm liana families [6]-[12], we reviewed all of the terms which used in describing the characteristics of stem transverse section to provide further identification and comparison, and a complete definition of endocarp characters follows the workers opinions (see Appendix 2).

\section{Results}

\subsection{Cambial Variants Terminology}

Cambial variants are divided into two major groups, namely, those derived from a single cambium and those derived from multiple cambia [12]. Single cambial variants are subdivided into five types: Multiple cambial variants are subdivided into four types. Multiple types of cambial variants occur in the family Fabaceae, Malpighiaceae, and Sapindaceae. The Malpighiaceae, for instance, shows a remarkable diversity of cambial variants, including species with dissected xylem, caused by the proliferation of non-lignified parenchyma [12]. In the present study, we add the dissected xylem (dispersed xylem segments) as one of the single cambium. In summary, we divided cambial variants into categories types, namely, six types originate from a single cambium and four types originate from multiple cambia (Table 1).

\subsection{Cambial Variants Photographs and Explanation}

In all sixteen investigated species, however, the photographs and observations are new. The results include the following: Figure 1(a): Cissampelos pareira L. var. hirsuta (DC.) Forman, Figure 1(b), c: Cocculus laurifolius DC., Figure 1(d), e: Cocculus orbiculatus (L.) DC., Figure 1(f): Cyclea gracillima Diels, Figure 2(a): Cyclea insularis (Makino) Hatusima, Figure 2(b): Cyclea ochiaiana (Yamam.) S. F. Huang \& T. C. Huang, Figure 2(c): Pericampylus glaucus (Lam.) Merr., Figure 2(d): Sinomenium acutum (Thunb.) Rehder \& E. H. Wilson, Figure 2(e): Stephania cephalantha Hayata, Figure 2(f): Stephania japonica (Thunb.) Miers., Figure 3(a): Stephania longa Lour., Figure 3(b): Stephania merrillii Diels, Figure 3(c): Stephania tetrandra S. Moore, Figure 3(d): Tinospora crispa (L.) Hook. F. et Thoms, Figure 3(e): Tinospora dentata Diels., Figure 3(f): Tinospora sinensis (Lour.) Merr.

\subsection{Species Characterization}

In the sixteen investigated species belonging to the family Menispermaceae in Taiwan, the climbing mode was twining and dextrorse stems. The stem transverse sections in these sixteen species are described (Table 2). Based on the stem transverse cross-section characteristics, we constructed a key to sixteen climber species as followed..

1. Vine 2 .

2. Number of collateral vascular bundles $>10$. Stephania cephalantha

-2 . Number of collateral vascular bundles $<10$. .Stephania longa

-1 . Shrub or liana ...3.

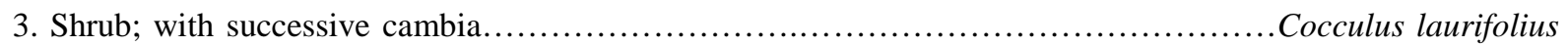
-3. Liana; without successive cambia. ...4. 
Table 1. Terms selected for morphological structure description of the stem cross-section in lianas.

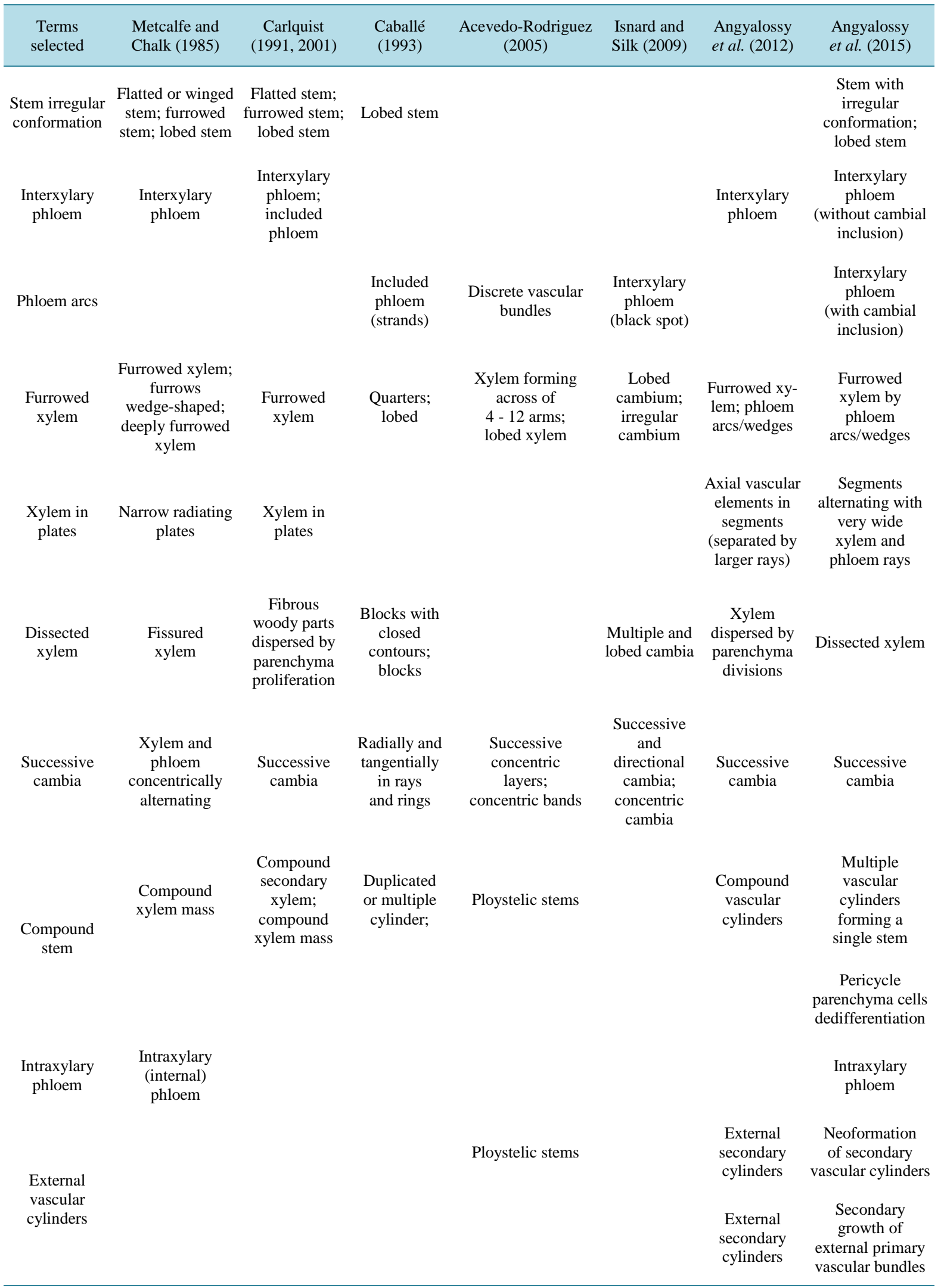




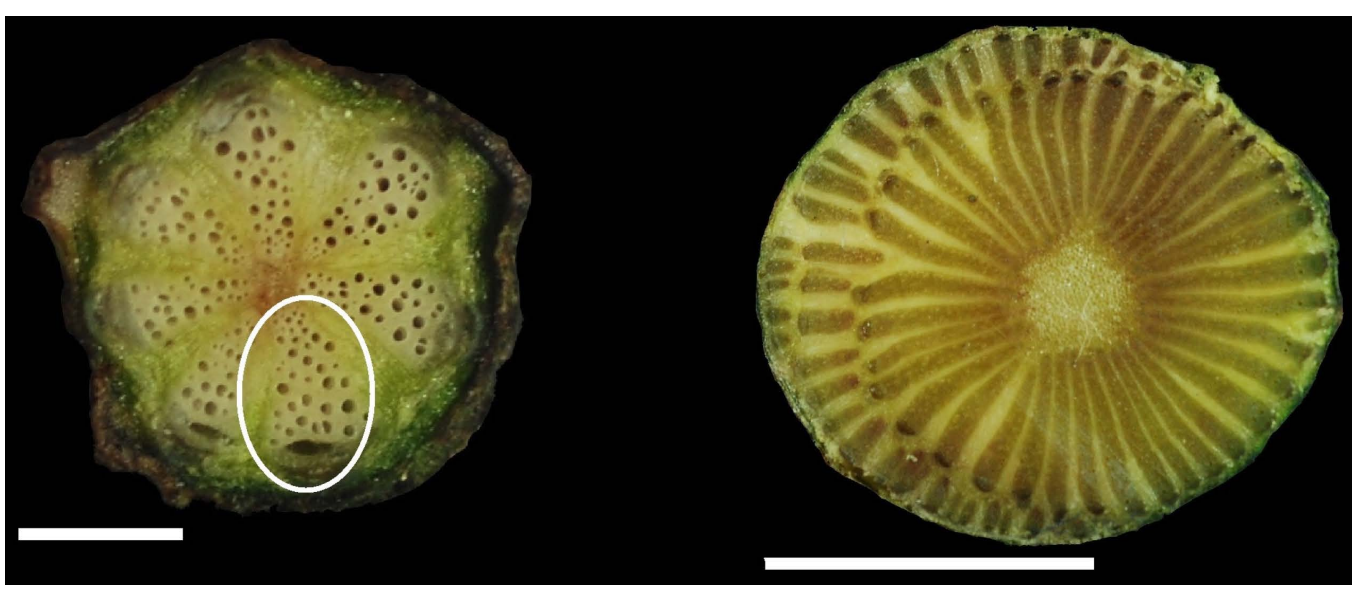

(a)

(b)

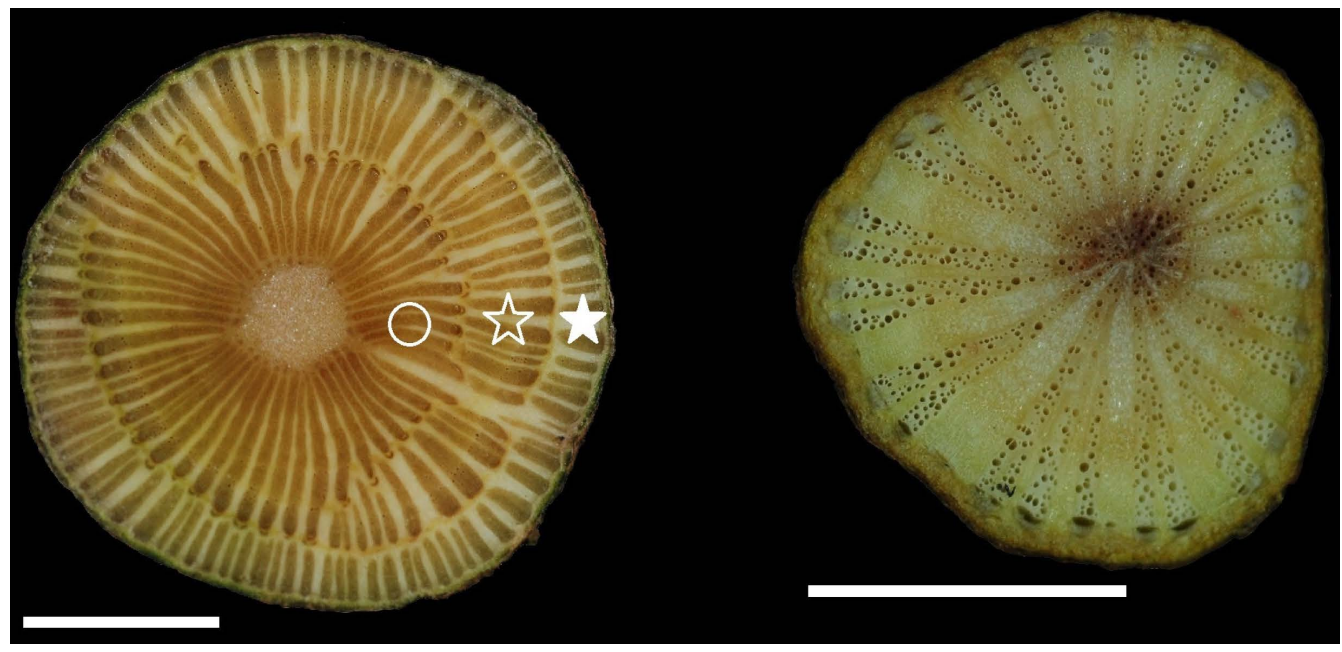

(c)

(d)

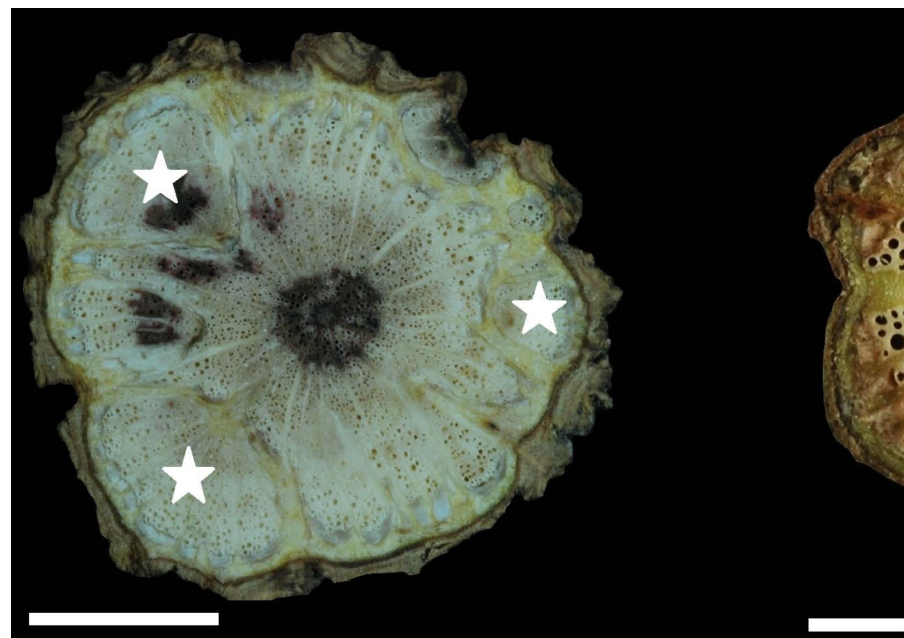

(e)

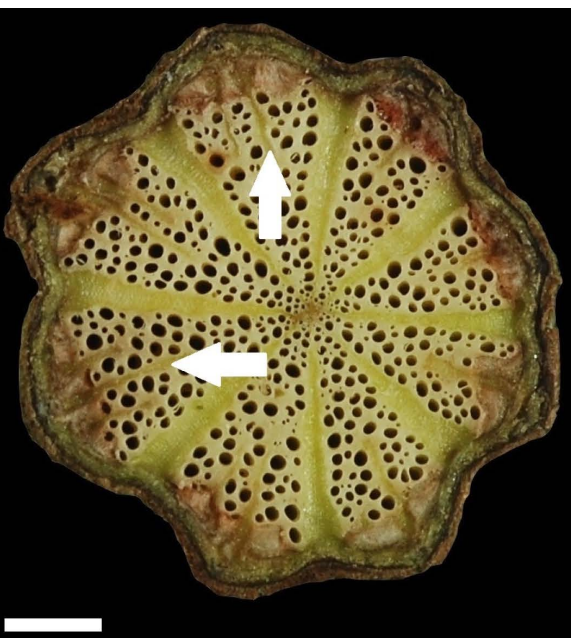

(f)

Figure 1. Stem transverse sections in members of the family Menispermaceae. (a) Cissampelos pareira var. hirsute, showing one collateral vascular bundle (cvb) (circle); (b) and (c), Cocculus laurifolius, 1st cambial production unit (CPU) (circle), 2ed CPU (empty asterisk), 3rd CPU (solid asterisk); (d) and (e), Cocculus orbiculatus, dissected xylem (asterisk); (f), Cyclea gracillima, each collateral vascular bundle formed split strips by parenchyma proliferation (arrows). Scale: (a) and (f) $=1$ $\mathrm{mm}$; (b)-(e) = $5 \mathrm{~mm}$. 


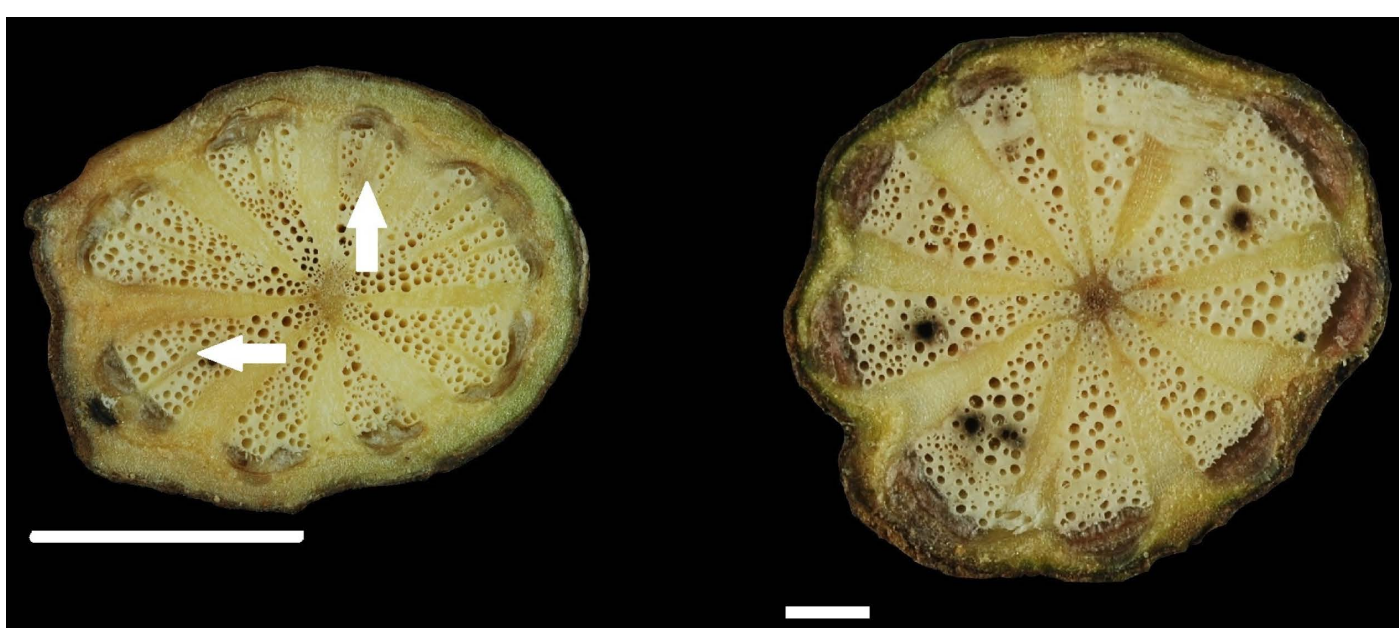

(a)

(b)

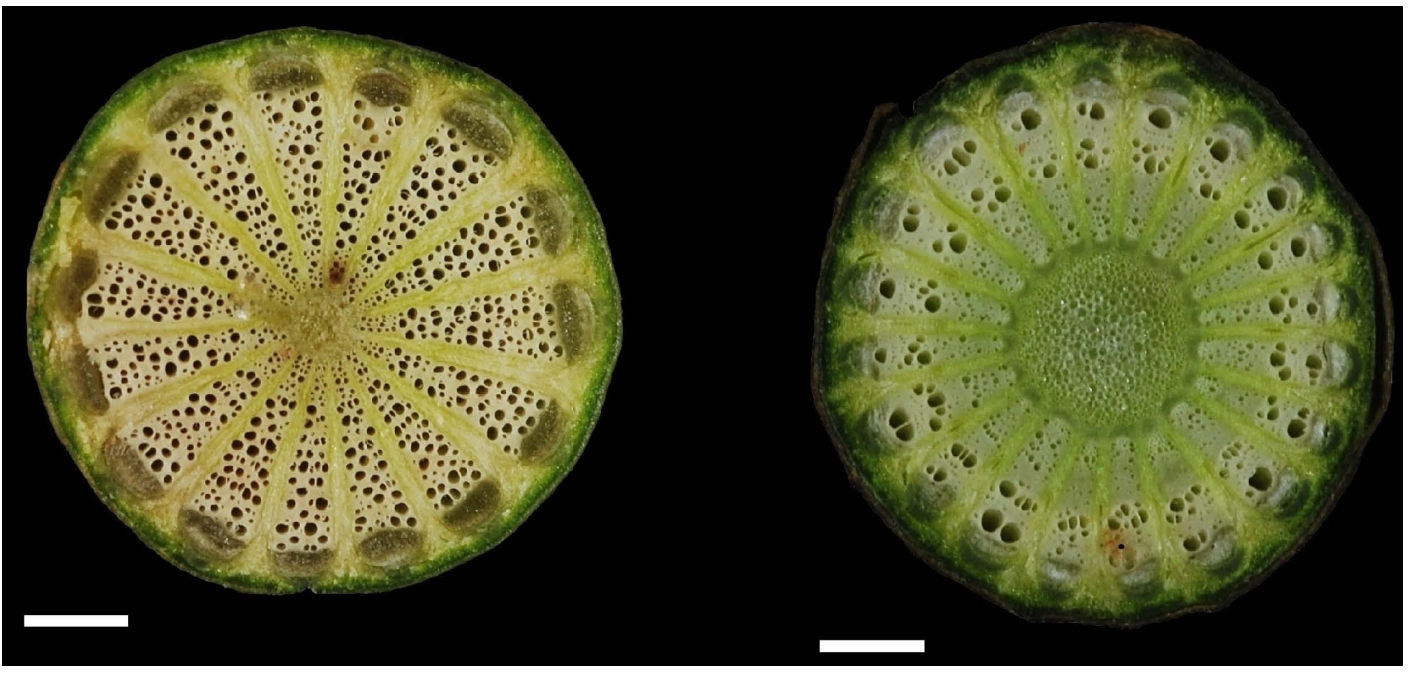

(c)

(d)

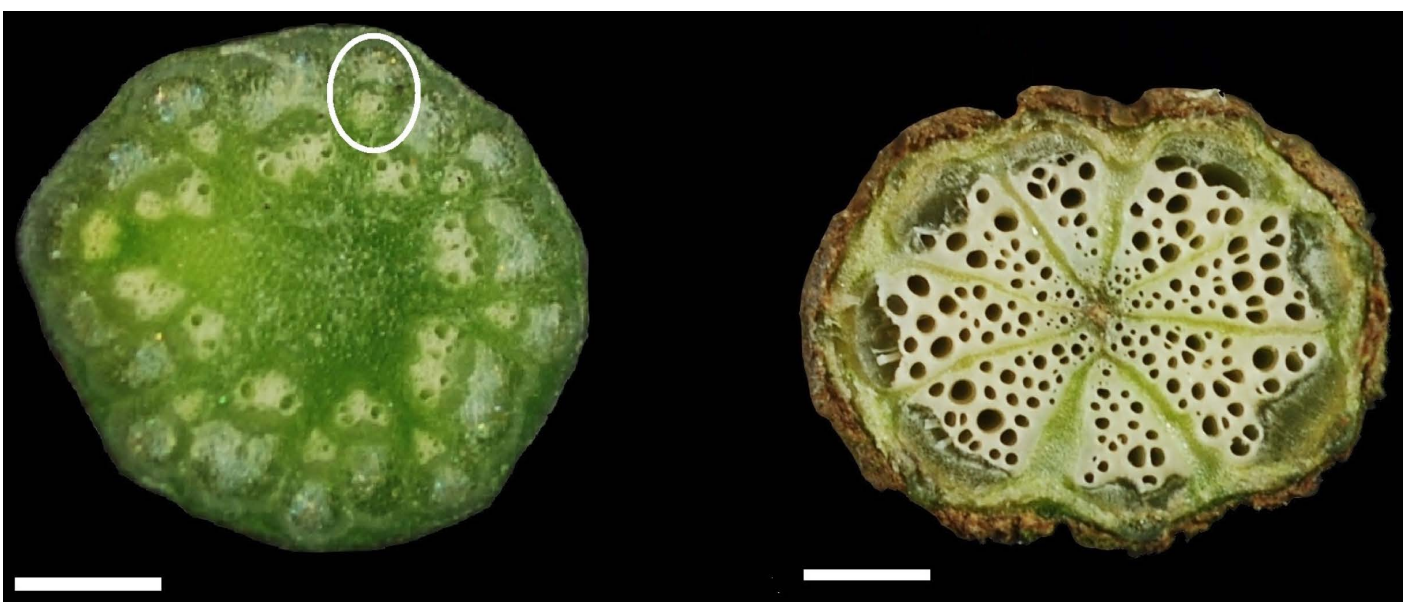

(e)

(f)

Figure 2. Stem transverse sections in members of the family Menispermaceae. (a) Cyclea insularis, each collateral vascular bundle formed split strips by parenchyma proliferation (arrows); (b) Cyclea ochiaiana; (c) Pericampylus glaucus; (d) Sinomenium acutum; (e) Stephania cephalantha, new vascular segment (nvs) (circle); (f) Stephania japonica. Scale: (a) = 5 mm; (b)-(f) $=1 \mathrm{~mm}$. 


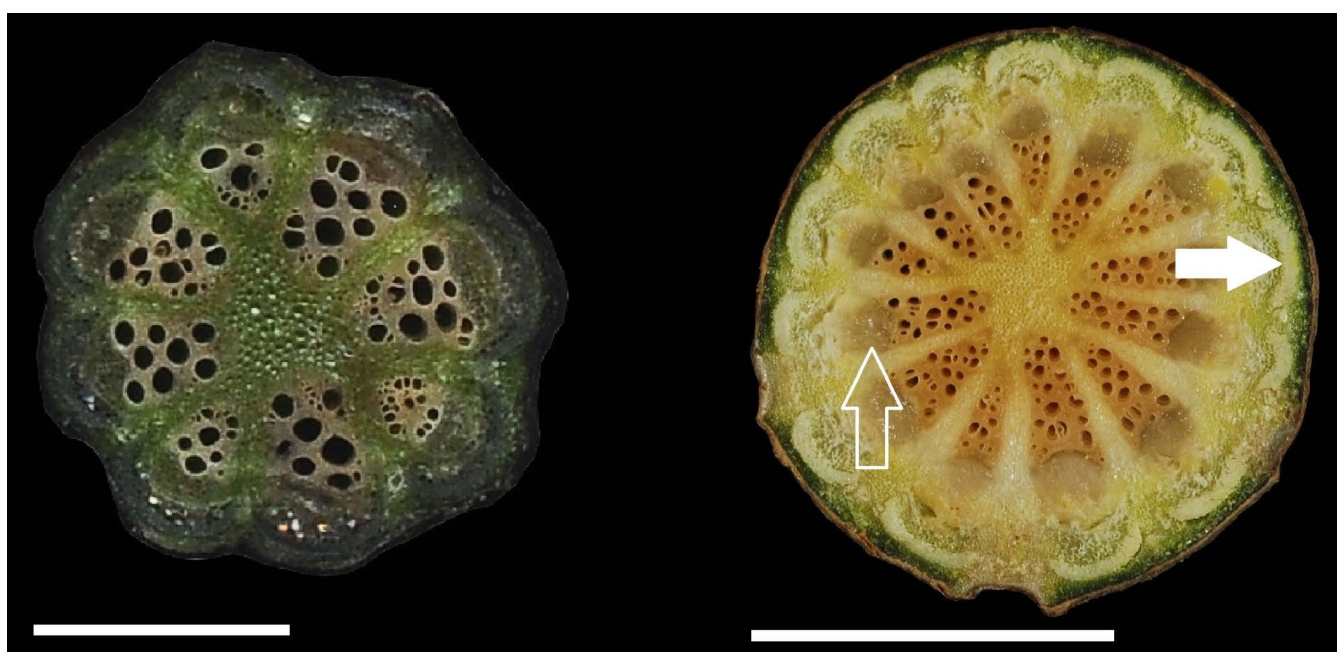

(a)

(b)

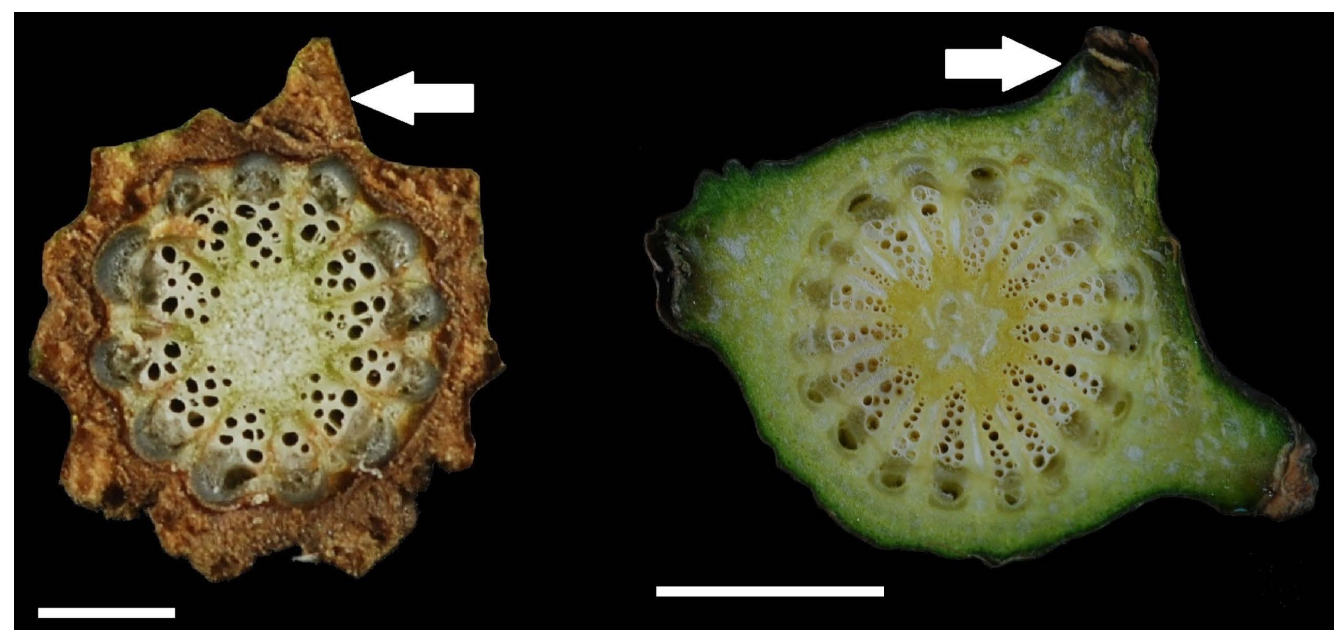

(c)

(d)

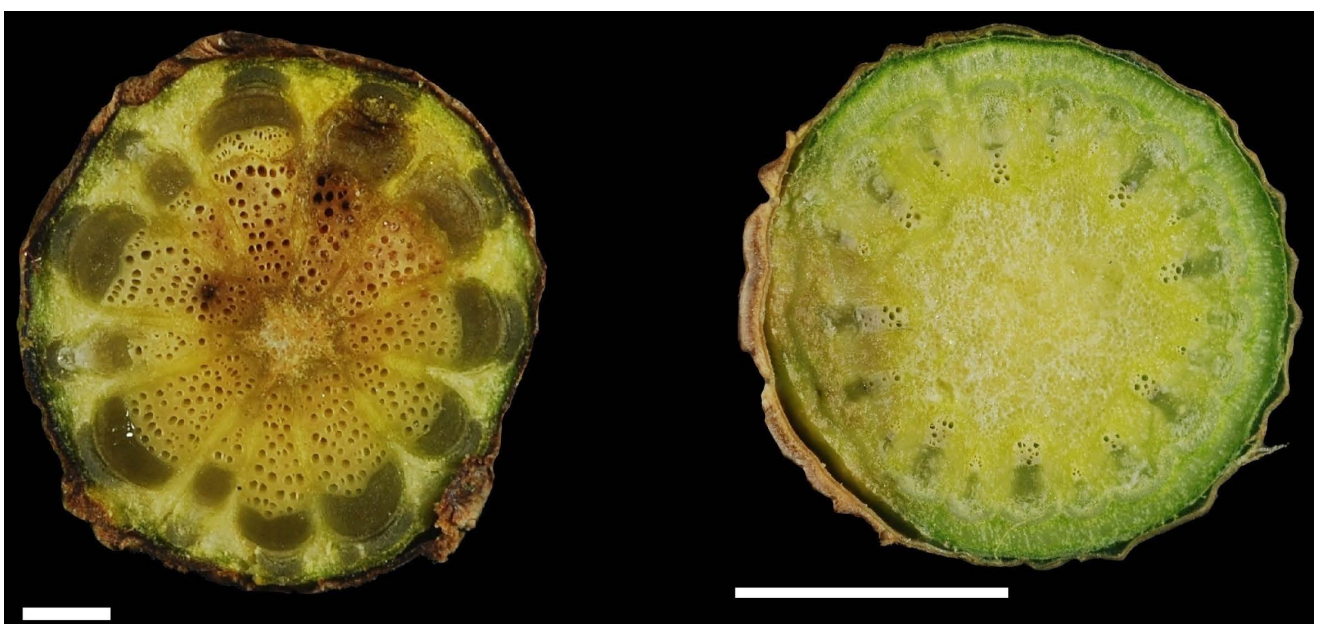

(e)

(f)

Figure 3. Stem transverse sections in members of the family Menispermaceae. (a) Stephania longa; (b) Stephania merrillii, showing phloem (empty arrow), phloem fiber (solid arrow); (c) Stephania tetrandra, showing conspicuous phellem layer (solid arrow); (d) Tinospora crispa, showing blunt tubercles on the epidermis (solid arrow); (e) Tinospora dentata; (f) Tinospora sinensis. Scale: (a), (c), and (e) = $1 \mathrm{~mm}$; (b), (d), and (f) $=5 \mathrm{~mm}$. 
4. Number of collateral vascular bundles approximately 8 - 9, with 1 - 3 split strips. .......................

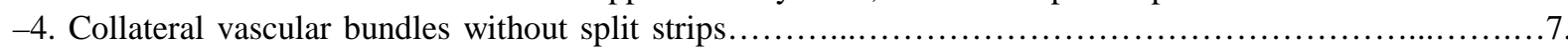

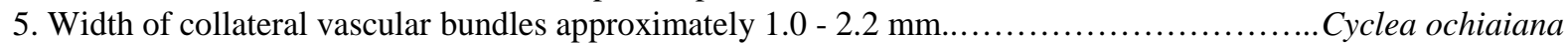

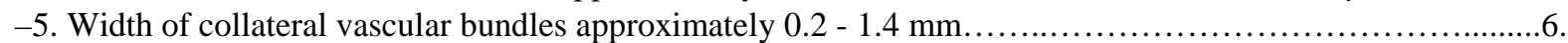

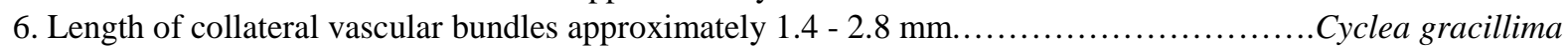

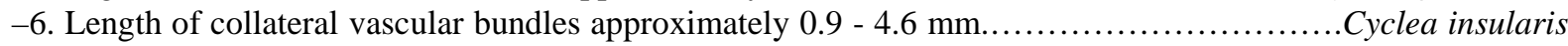

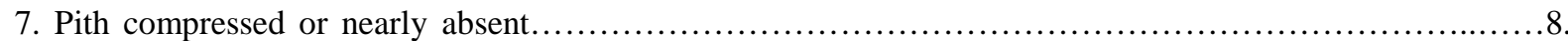

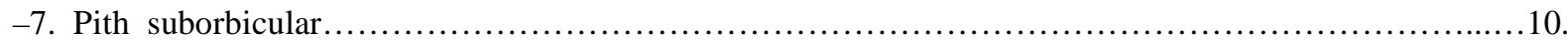

8. Number of collateral vascular bundles $>10 \ldots \ldots \ldots \ldots \ldots \ldots \ldots \ldots \ldots \ldots \ldots \ldots \ldots \ldots \ldots \ldots \ldots$. Cocculus orbiculatus

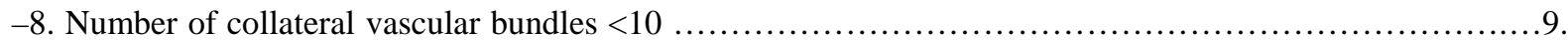

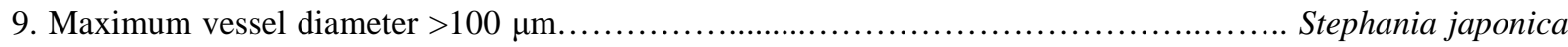

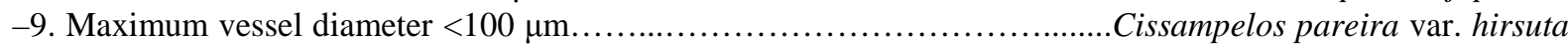

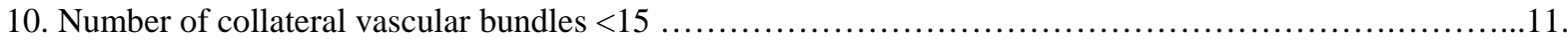

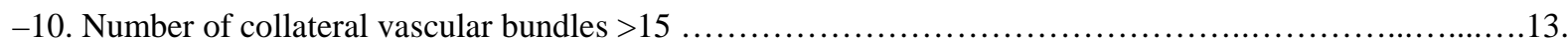

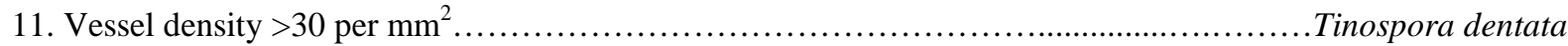

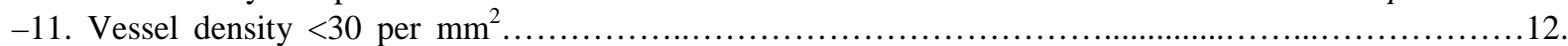

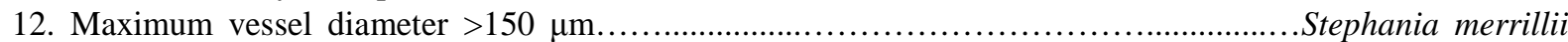

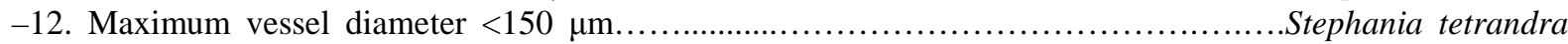

13. Number of vessels per xylem bundle $<10 \ldots \ldots \ldots \ldots \ldots \ldots \ldots \ldots \ldots \ldots \ldots \ldots \ldots \ldots \ldots \ldots \ldots \ldots \ldots \ldots \ldots$.

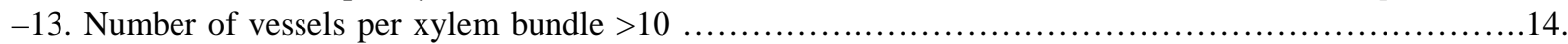

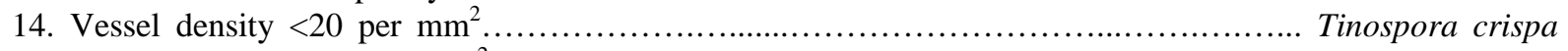

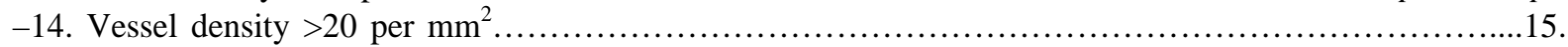

15. Ray width towards periphery remaining the same..................................... Sinomenium acutum

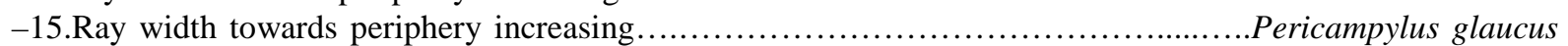

\section{Discussion}

Members of the family Menispermaceae are extensively distributed in the low mountainous forests of Taiwan. In the present study, a newly recorded species, Cissampelos pareira var. hirsuta (Figure 1), is very rare and is found only in Liuqiu Township, Pingtung County. Sinomenium acutum is widely distributed throughout China; however, in Taiwan, it is found only in Siyuan Wind Gap, Yilan County. Cyclea ochiaiana, Stephania merrillii, and Tinospora dentata are endemic to Taiwan, in which C. ochiaiana is found at middle altitudes, S. merrillii is found only on Lanyu Island and Green Island, T. dentata is found at low altitudes in southern Taiwan (Appendix 1). Morphological characteristics of stem transverse section in these 16 investigated species of Menispermaceae in Taiwan were mentioned in Table 2.

Plants in the genus Cocculus typically have successive cambia and/or xylem in plates. In the present study, Cocculus laurifolius was the only species with successive cambia (Figure 1(b) and Figure 1(c)); however, Cocculus orbiculatus had a combination of xylem in plates (Figure 1(d)) and dissected xylem (Figure 1(e)). The dissected xylem is an anomalous structure formed by the division of parenchyma cells, for example, in Bauhinia championii (Fabaceae) [7] [20]. In comparison with normal xylem, dissected xylem has a more cracked appearance. The original xylem is broken and scattered, because phloem dilatation and the proliferation of parenchyma cells gradually result in the formation of several fragments [9]. Dissected xylem is also termed "blocks" [10] or "multiple and lobed cambia" [6] (Table 1). A single plant may have more than one type of cambial variant; accordingly, in our present study, Cocculus orbiculatus showed two types of cambial variant (Figure 1(d) and Figure 1(e)).

Lianas have dimorphic vessels. Large vessels have a diameter of $>100 \mu \mathrm{m}$, and small vessels have a diameter of $<100 \mu \mathrm{m}$ [21]. In shrubs, the vessel diameter does not exceed $100 \mu \mathrm{m}$. Larger vessels provide efficient water conduction but are prone to embolization. If xylem embolization occurs, smaller vessels are used for hydraulic conduction. This alternative function regarding vessel dimorphism simultaneously favors the efficiency and safety of water conduction [22]. With the exception of Cissampelos pareira var. hirsuta and Cocculus laurifolius, the lianas and vines observed in the present study had large vessels; in Cocculus laurifolius, the vessel diameter was $<50 \mu \mathrm{m}$. A few plants such Abuta grandifolia (Menispermaceae) are known to combine lianas and shrubs or trees in their life stage [21]. In A. grandifolia, the vessel diameter is three-fold higher at the liana stage 
Table 2. Morphological characteristics of stem transverse section in Menispermaceae in Taiwan.

\begin{tabular}{|c|c|c|c|c|c|c|c|c|c|c|c|c|c|c|c|}
\hline Species & Habits & $\begin{array}{l}\text { Cambial } \\
\text { variants }\end{array}$ & $\begin{array}{l}\text { Stem } \\
\text { diameter } \\
(\mathrm{mm})\end{array}$ & $\begin{array}{l}\text { Shape } \\
\text { of pith }\end{array}$ & $\begin{array}{c}\text { Pith } \\
\text { diameter } \\
(\mathrm{mm})\end{array}$ & $r \begin{array}{l}\text { Number } \\
\text { of cvb }\end{array}$ & $\begin{array}{l}\text { Parenchyma } \\
\text { proliferation }\end{array}$ & $\begin{array}{l}\text { Length } \\
\text { of cvb } \\
(\mathrm{mm})\end{array}$ & $\begin{array}{l}\text { Width } \\
\text { of cvb } \\
(\mathrm{mm})\end{array}$ & $\begin{array}{l}\text { Length } \\
\text { of rays } \\
(\mathrm{mm})\end{array}$ & $\begin{array}{l}\text { Width } \\
\text { of rays } \\
(\mathrm{mm})\end{array}$ & $\begin{array}{l}\text { Outwards } \\
\text { change } \\
\text { of ray } \\
\text { width }\end{array}$ & $\begin{array}{c}\text { Vessels/ } \\
\text { per xylem }\end{array}$ & $\begin{array}{l}\text { Vessels } \\
/ \mathrm{mm}^{2}\end{array}$ & $\begin{array}{c}\text { Vessel } \\
\text { diameter } \\
\quad(\mu \mathrm{m})\end{array}$ \\
\hline $\begin{array}{l}\text { Cissampelos } \\
\text { pareira L. var. } \\
\text { hirsuta (DC.) } \\
\text { Forman }\end{array}$ & Liana & $\begin{array}{l}\text { Xylem in } \\
\text { plates }\end{array}$ & 3.0 & Irregular & - & $7-8$ & 0 & $0.9-1.3$ & $0.4-0.6$ & $0.5-0.9$ & $0.2-0.4$ & 1 & 30 & 60 & $2-86$ \\
\hline $\begin{array}{c}\text { Cocculus } \\
\text { laurifolius } \\
\text { DC. }\end{array}$ & Shrub & $\begin{array}{c}\text { Successive } \\
\text { cambia }\end{array}$ & $8.3-14.8$ & Suborbicular & $1.4-2.5$ & $37-50$ & 0 & $2.0-5.0$ & $0.1-0.5$ & $1.9-4.7$ & $0.1-0.7$ & $0 / 1$ & - & - & $<50$ \\
\hline $\begin{array}{l}\text { Cocculus } \\
\text { orbiculatus } \\
\text { (L.) DC. }\end{array}$ & Liana & $\begin{array}{l}\text { Xylem in } \\
\text { plates, } \\
\text { dissected } \\
\text { xylem }\end{array}$ & $8.6-15.6$ & Nearly absent & - & $15-17$ & 1 & $2.7-7.1$ & $0.1-1.0$ & $2.3-6.0$ & $0.1-1.2$ & 1 & $68-185$ & $31-68$ & $1-193$ \\
\hline $\begin{array}{l}\text { Cyclea gracil- } \\
\text { lima Diels }\end{array}$ & Liana & $\begin{array}{l}\text { Xylem in } \\
\text { plates }\end{array}$ & $4.0-5.7$ & Nearly absent & - & 8 & 1 & $1.4-2.8$ & $0.2-0.8$ & $1.1-2.4$ & $0.3-0.5$ & 1 & $31-67$ & $35-36$ & $1-177$ \\
\hline $\begin{array}{c}\text { Cyclea } \\
\text { insularis } \\
\text { (Makino) } \\
\text { Hatusima }\end{array}$ & Liana & $\begin{array}{l}\text { Xylem in } \\
\text { plates }\end{array}$ & $3.5-9.4$ & $\begin{array}{l}\text { Compressed, } \\
\text { suborbicular }\end{array}$ & 0.6 & 8 & 1 & $0.9-4.6$ & $0.3-1.4$ & $0.7-3.5$ & $0.2-1.1$ & 1 & $21-103$ & $32-33$ & $8-202$ \\
\hline $\begin{array}{l}\text { Cyclea } \\
\text { ochiaiana } \\
\text { (Yamam.) S. } \\
\text { F. Huang \& T. } \\
\text { C. Huang, }\end{array}$ & Liana & $\begin{array}{l}\text { Xylem in } \\
\text { plates }\end{array}$ & $7.3-10.0$ & Suborbicular & 0.6 & 9 & 1 & $2.5-5.9$ & $1.0-2.2$ & $2.2-4.8$ & $0.5-1.1$ & 1 & $94-182$ & $34-38$ & $3-222$ \\
\hline $\begin{array}{l}\text { Pericampylus } \\
\text { glaucus } \\
\text { (Lam.) Merr. }\end{array}$ & Liana & $\begin{array}{l}\text { Xylem in } \\
\text { plates }\end{array}$ & $4.5-5.8$ & Suborbicular & $0.7-1.3$ & $15-16$ & 0 & $1.1-2.5$ & $0.4-0.9$ & $0.7-2.0$ & $0.1-0.3$ & 1 & $19-69$ & $39-66$ & $1-154$ \\
\hline $\begin{array}{c}\text { Sinomenium } \\
\text { acutum } \\
\text { (Thunb.) } \\
\text { Rehder \& } \\
\text { E. H. Wilson, }\end{array}$ & Liana & $\begin{array}{l}\text { Xylem in } \\
\text { plates }\end{array}$ & $5.0-5.8$ & Suborbicular & $1.7-1.9$ & $20-22$ & 0 & $1.2-2.0$ & $0.3-0.6$ & $0.7-1.5$ & $0.1-0.2$ & 0 & $28-55$ & $63-78$ & $2-235$ \\
\hline $\begin{array}{c}\text { Stephania } \\
\text { cephalantha } \\
\text { Hayata }\end{array}$ & Vine & $\begin{array}{l}\text { Xylem in } \\
\text { plates }\end{array}$ & 3.5 & Suborbicular & 1.4 & 17 & 0 & $0.5-0.9$ & $0.2-0.6$ & - & - & $\mathrm{i}$ & 11 & 35 & $2-125$ \\
\hline $\begin{array}{c}\text { Stephania } \\
\text { japonica } \\
\text { (Thunb.) } \\
\text { Miers }\end{array}$ & Liana & $\begin{array}{l}\text { Xylem in } \\
\text { plates }\end{array}$ & $3.8-4.0$ & Nearly absent & - & 8 & 0 & $1.1-2.1$ & $0.7-1.2$ & $0.9-1.5$ & $0.1-0.4$ & $0 / 1$ & $28-29$ & $35-40$ & 1 - 199 \\
\hline $\begin{array}{c}\text { Stephania } \\
\text { longa Lour. }\end{array}$ & Vine & $\begin{array}{l}\text { Xylem in } \\
\text { plates }\end{array}$ & 2.1 & Suborbicular & 0.5 & 8 & 0 & $0.5-0.8$ & $0.3-0.5$ & $0.3-0.4$ & $0.1-0.2$ & 0 & 17 & 51 & $6-138$ \\
\hline $\begin{array}{c}\text { Stephania } \\
\text { merrillii } \\
\text { Diels }\end{array}$ & Liana & $\begin{array}{l}\text { Xylem in } \\
\text { plates }\end{array}$ & $7.8-7.9$ & Suborbicular & $1.4-1.5$ & $11-13$ & 0 & $1.6-2.7$ & $0.6-1.1$ & $0.9-1.6$ & $0.1-0.5$ & 1 & $15-16$ & $17-18$ & $11-207$ \\
\hline $\begin{array}{c}\text { Stephania } \\
\text { tetrandra S. } \\
\text { Moore }\end{array}$ & Liana & $\begin{array}{l}\text { Xylem in } \\
\text { plates }\end{array}$ & 3.9 & Suborbicular & 0.9 & 12 & 0 & $0.6-1.0$ & $0.4-0.5$ & $0.4-0.6$ & 0.1 & 1 & 7 & 19 & $8-136$ \\
\hline $\begin{array}{c}\text { Tinospora } \\
\text { crispa (L.) } \\
\text { Hook. F. et } \\
\text { Thoms }\end{array}$ & Liana & $\begin{array}{l}\text { Xylem in } \\
\text { plates }\end{array}$ & $9.6-11.0$ & Suborbicular & $2.2-3.7$ & 18 & 0 & $0.1-2.7$ & $0.2-0.9$ & $1.1-1.9$ & $0.2-0.4$ & 1 & $5-16$ & $7-16$ & $6-295$ \\
\hline $\begin{array}{c}\text { Tinospora } \\
\text { dentata Diels. }\end{array}$ & Liana & $\begin{array}{l}\text { Xylem in } \\
\text { plates }\end{array}$ & $3.8-6.2$ & Suborbicular & 0.9 & $11-12$ & 0 & $0.9-2.4$ & $0.4-1.1$ & $0.6-1.6$ & $0.1-0.3$ & 1 & $34-45$ & $40-67$ & $4-117$ \\
\hline $\begin{array}{c}\text { Tinospora } \\
\text { sinensis } \\
\text { (Lour.) Merr. }\end{array}$ & Liana & $\begin{array}{l}\text { Xylem in } \\
\text { plates }\end{array}$ & $5.9-10.1$ & Suborbicular & $2.9-4.6$ & $19-20$ & 0 & $0.5-1.8$ & $0.2-0.5$ & - & - & i & $7-9$ & $11-14$ & $2-123$ \\
\hline
\end{tabular}

Note: $\mathrm{cvb}=$ collateral vascular bundles; parenchyma proliferation: $0=$ absent, $1=$ present; outwards change of ray width: $0=$ no changed, $1=$ increasing, $\mathrm{i}=$ immature.

than at the shrub stage. In comparison with trees and shrubs, lianas have much larger vessels and a lower vessel density; moreover, they combine soft and hard tissue characteristics, which ensure excellent water conduction, elasticity, and toughness. These traits are collectively termed lianescent properties [12].

In the present study, Cocculus orbiculatus had the longest collateral vascular bundles (cvb, Figure 1(a)) (2.7 - 
$7.1 \mathrm{~mm})$, longest rays $(2.3-6.0 \mathrm{~mm})$ and widest rays $(0.1-1.2 \mathrm{~mm})$ (Figure $1(\mathrm{~d})$ and Figure $1(\mathrm{e}))$. Cyclea ochiaiana had the widest collateral vascular bundles $(1.0-2.2 \mathrm{~mm})$ (Figure 2(b)). Sinomenium acutum had the highest vessel density (63- 78 per $\mathrm{mm}^{2}$ ) and the width of the rays did not increase towards the periphery (Figure 2(d)). Tinospora crispa had the lowest vessel density $\left(7-16\right.$ per $\mathrm{mm}^{2}$ ) (Figure 3(d)) and the largest vessel diameter (6 - $295 \mu \mathrm{m})$.

In Cyclea gracillima, C. insularis, and C. ochiaiana, the transverse section of the stem was xylem in plates. In these three species, approximately 8 - 9 collateral vascular bundles (crb) were present, and each collateral vascular bundle developed 1 - 3 split strips (Figure 1(f); Figure 2(a) and Figure 2(b); arrows). A mature stem of Ungulipetalum filipendulum (Menispermaceae) was identified based on parenchyma proliferation [23]. The trait of 1 - 3 split strips is related to the proliferation of non-lignified parenchyma. This trait may be derived partly from the cambium of the stem, through a decrease in the size of the xylem and hence an increase in the size of the phloem, thereby leading to the formation of split strips.

The cambial variant of xylem in plates was referred to as a cambial production unit (CPU) (Figure 1(c)), which comprises pith, secondary xylem, fascicular cambium, secondary phloem (Figure 3(b)), primary phloem, and phloem fibers (Figure 3(b)) [24]. A large number of CPU units constitute a successive cambia. In Cissampelos and Cocculus, successive cambia develop, whereas in Tinospora, xylem in plates develops [24]. In Cocculus, the first CPU (Figure 1(c)) can only be produced when the stem diameter is $\leq 1.1 \mathrm{~cm}$, and the second CPU (Figure 1(c)) is formed when the stem diameter is $>1.1 \mathrm{~cm}$ [24]. In the present study, the stem diameter in Cissampelos pareira var. hirsuta was $3.0 \mathrm{~mm}$, and therefore we were unable to observe a second CPU. In Cocculus orbiculatus, the maximum stem diameter was approximately $15.6 \mathrm{~mm}$, and this was expected to enable the development of the second CPU; however, an anomalous structure of dissected xylem was formed instead of a second CPU. In Cocculus laurifolius, the stem diameter was within the range $8.3-14.8 \mathrm{~mm}$, and this species produced second and third CPUs. In Tinospora, the stem diameter was $>2.7 \mathrm{~cm}$, but the stem transverse section was xylem in plates [24]. In the present study, the maximum stem diameters of Tinospora crispa, T. dentata, and $T$. sinensis were equivalent to $1.1 \mathrm{~cm}, 0.6 \mathrm{~cm}$, and $1.0 \mathrm{~cm}$, respectively, the stem transverse section was xylem in plates in deed. Taken together, our results imply that a stem diameter of $>1.1 \mathrm{~cm}$ is not necessarily a prerequisite for the formation of a second CPU. Further research into cambial variants of genera in the family Menispermaceae in Taiwan are required to more fully examine this phenomenon.

In the 16 investigated species belonging to the family Menispermaceae in Taiwan, the climbing mode was twining and dextrorse stems. Twining and dextrorse stems constitutes the main climbing mode in tropical regions [25], and it can be used to identify climbing plants. The front end of a twining stem can be rotated around the body of the host to initiate climbing, or it can become attached to the host in a process called circumnutation [26]. The twining and dextrorse stems climbing mode can be subdivided into sinistrorse and dextrorse [27]. For example, the family Caprifoliaceae has a sinistrorse climbing mode, whereas the families Lardizabalaceae and Aristolochiaceae have dextrorse climbing modes [5].

With the exception of Cocculus laurifolius, all the species investigated in the present study had xylem in plates, and these plates were separated by very wide phloem rays. Wide phloem rays are derived from parenchyma cells that are arranged radially around the transverse section of the stem and are not connected to each other [17]. This trait favors the flexibility of liana stems and protects each side of the xylem vessels, thereby resulting in a continuously twisted stem [28]. Other families with wide rays include the Actinidiaceae, Araliaceae, Cactaceae, Dilleniaceae, Icacinaceae, Lardizabalaceae, Passifloraceae, Piperaceae, Schisandraceae, and Vitaceae [8]. The wide rays of the family Vitaceae are similar to those of the family Menispermaceae but can be distinguished according to the phloem shape; in the family Vitaceae, the phloem has a flame-like shape, whereas in the family Menispermaceae, the phloem has a cap-like shape.

Tinospora sinensis and T. crispa are used medicinally in Taiwan, and therefore they are termed bitter vines. $T$. sinensis is sometimes erroneously used to refer to T. crispa and vice versa. T. crispa populations are scattered and naturalized in central and southern Taiwan, at the edges of low-altitude forests. T. crispa has no reproductive organs, and therefore it reproduces primarily via stem asexual regeneration. The species $T$. crispa also shows blunt tubercles on the epidermis (Figure 3(d)). T. sinensis has not previously been found in the field in Taiwan; in the present study, only female flowers were observed.

In the present study, the highest number of collateral vascular bundles was found in Cocculus laurifolius (approximately 37 - 50), followed by Sinomenium acutum (approximately 20 - 22). In Cyclea gracillima, C. insularis, and C. ochiaiana, the widths of the 8 - 9 collateral vascular bundles were within the range $3.5-10 \mathrm{~mm}$. In $S$. 
acutum the width of the collateral vascular bundles was within the range $0.3-0.6 \mathrm{~mm}$. In Stephania cephalantha S. japonica, S. longa, S. merrillii, and S. tetrandra, the number of collateral vascular bundles did not increase according to the stem diameter. Our results imply that the number of collateral vascular bundles is not related to the stem diameter. Hence, the characteristics and numbers of collateral vascular bundles can be used to identify species belonging to the family Menispermaceae in Taiwan. However, the species Stephania tetrandra shows conspicuous phellem layer (Figure 3(c)).

The information of families of lianas that form various specific anomalous structures and the terms used to explain the anatomical characteristics of stems (Table 1) are very important. However, these families were mainly distributed in the New World Division, and the list did not include families commonly occurring in Asia. Our present findings regarding the anomalous structures of families of lianas in Taiwan will facilitate the classification of cambial variants in liana ecology.

\section{Conclusion}

In the present study, we examined the climbing modes and anomalous structure of climber stems in 16 species belonging to the family Menispermaceae in Taiwan. Cocculus laurifolius is a shrub, Stephania cephalantha and S. longa are vines, and the remaining 13 species are lianas. In all the investigated species, the climbing mode was twining and dextrorse stems. The anomalous structure of the stems in Cocculus orbiculatus comprised xylem in plates and dissected xylem which was involved parenchyma proliferation. In the genus Cyclea, each collateral vascular bundle had 1 - 3 split strips. Cocculus orbiculatus had the longest collateral vascular bundles and longest wide rays. Cyclea ochiaiana had the widest collateral vascular bundles and widest rays. Sinomenium acutum had the highest vessel density. Our findings highlight new anatomical characteristics, for example, the number of collateral vascular bundles and dissected xylem, for species identification in the family Menispermaceae in Taiwan.

\section{Acknowledgements}

We thank the staffs of PPI Herbariun, National Pingtung University of Science and Technology for providing the fresh stem specimens about the family Menispermaceae, and anonymous reviewers for providing comments that improved an earlier draft of this manuscript.

\section{References}

[1] Ortiz, R.D.C., Kellogg, E.A. and Werff, H.V.D. (2007) Molecular Phylogeny of the Moonseed Family (Menispermaceae): Implications for Morphological Diversification. America Journal of Botany, 94, 1425-1438. http://dx.doi.org/10.3732/ajb.94.8.1425

[2] Sharma, A., Gupta, A. and Batra, S.S.A. (2010) Tinospora cordifolia (Willd.) Hook. F. \& Thomson-A Plant with Immense Economic Potential. Journal of Chemical and Pharmacology Research, 2, 327-333.

[3] Jiang, M.-L. (2006) Studies on the Medicinal Plant Resource of Menispermaceae in Taiwan. M.S. Thesis, National Chung Hsing University, Taiwan. (In Chinese with English Abstract)

[4] Huang, S.F. and Huang, T.C. (1996) Menispermaceae. In: Huang, T.C. and Editorial Committee, Flora of Taiwan, Vol. 2, Department of Botany, NTU, Taipei, 591-607.

[5] Chen, C.-F., Chen, P.-H. and Yang, S.-Z. (2013) Climbing Modes of Climbers in Central and Southern Regions of Taiwan. Quarterly Journal of Chinese Forestry, 46, 441-460. (In Chinese with English Abstract)

[6] Isnard, S. and Silk, W.K. (2009) Moving with Climbing Plants from Charles Darwin's Time into the 21st Century. America Journal of Botany, 96, 1205-1221. http://dx.doi.org/10.3732/ajb.0900045

[7] Metcalfe, C.R. and Chalk, L. (1985) Anatomy of the Dicotyledons: Volume II: Wood Structure and Conclusion of the General Introduction, 2nd Edition, Oxford University Press, New York.

[8] Carlquist, S. (1991) Anatomy of Vine and Liana Stems: A Review and Synthesis. In: Putz, F.E. and Mooney H.A., Eds., The Biology of Vines, Cambridge University Press, Cambridge, 53-71.

[9] Carlquist, S. (2001) Comparative Wood Anatomy. Systematic, Ecological, and Evolutionary Aspects of Dicotyledon Wood. Spinger-Verlag Press, Germany. http://dx.doi.org/10.1007/978-3-662-04578-7

[10] Caballé, G.U.Y. (1993) Liana Structure, Function and Selection: A Comparative Study of Xylem Cylinders of Tropical Rainforest Species in Africa and America. Botany Journal of Linnean Society, 113, 41-60.

http://dx.doi.org/10.1111/j.1095-8339.1993.tb00328.x 
[11] Angyalossy, V., Angeles, G., Pace, M.R., Lima, A.C., Dias-Leme, C.L., Lohmann, L.G. and Madero-Vega, C. (2012) An Overview of the Anatomy, Development and Evolution of the Vascular System of Lianas. Plant Ecology and Diversity, 5, 167-182. http://dx.doi.org/10.1080/17550874.2011.615574

[12] Angyalossy, V., Pace, M.R. and Lima, A.C. (2015) Liana Anatomy: A Broad Perspective on Structural Evolution of the Vascular System. In: Schnitzer, S.A. and Bongers, F., Eds., Ecology of Lianas, Wiley Blackwell, Chichester, 253-287. http://dx.doi.org/10.1002/9781118392409.ch19

[13] Putz, F.E. and Mooney, H.A. (1991) The Biology of Vines. Cambridge University Press, Cambridge.

[14] Mennega, A.W. (1982) Stem Structure of the New World Menispermaceae. Journal of Arnold Arboritum, 63, $145-172$.

[15] Carlquist, S. (1996) Wood and Stem Anatomy of Menispermaceae. Aliso, 14, 155-170.

[16] Yang, S.-Z. and Chen, P.-H. (2015) Classifying Taiwan Lianas with Radiating Plates of Xylem. Taiwania, 60, 151-159.

[17] Tsai, S.-H. (1973) Anatomy of Plant. National Institute for Compilation and Translation, Taipei. (In Chinese)

[18] Beck, C.B. (2011) An Introduction to Plant Structure and Development: Plant Anatomy for the Twenty-First Century. 2nd Edition, Cambridge University Press, Cambridge.

[19] Yang, S.-Z., Chen, P.-H., Chen, C.-F. and Chen, C.-W. (2016) Identity of a Problematic Menispermaceae in Taiwan, Cissampelos pareira L. var. hirsuta (Buch.-Ham. ex DC.) Forman. Taiwania, 61, 27-33.

[20] Yang, S.-Z., Chen, P.-H. and Chen, Y.-J. (2014) Classification on Anomalous Structure of Lianas Stem. Journal of National Taiwan Museum, 67, 47-76. (In Chinese with English Abstract)

[21] Tamaio, N. and das Neves Brandes, A.F. (2010) Xylem Structure of Successive Rings in the Stem of Abuta grandifolia (Menispermaceae) a Statistical Approach. International Association Wood Anatomy Journal, 31, 309-316. http://dx.doi.org/10.1163/22941932-90000025

[22] Lima, A.C., Pace, M.R. and Angyalossy, V. (2010) Seasonality and Growth Rings in Lianas of Bignoniaceae. Trees, 24, 1045-1060. http://dx.doi.org/10.1007/s00468-010-0476-z

[23] Tamaio, N., Vieira, R.C. and Angyalossy, V. (2009) Origin of Successive Cambia on Stem in Three Species of Menispermaceae. Reviews in Brasilia Botany, 32, 839-848. http://dx.doi.org/10.1590/S0100-84042009000400021

[24] Jacques, F.M.B. and de Franceschi, D. (2007) Menispermaceae Wood Anatomy and Cambial Variants. International Association Wood Anatomy Journal, 28, 139-172. http://dx.doi.org/10.1163/22941932-90001631

[25] Senbeta, F., Schmitt, C., Denich, M., Sebsebe, D., Viek, P.L.G., Preisinger, H. and Teketay, D. (2005) The Diversity and Distribution of Lianas in the Afromontane Rain Forests of Ethiopia. Diversity Distribution, 11, 443-452. http://dx.doi.org/10.1111/j.1366-9516.2005.00180.x

[26] Acevedo-Rodríguez, P. (2005) Vines and Climbing Plants of Puerto Rico and the Virgin Islands. The United States National Herbarium Vol. 51. Department of Botany, National Museum of Natural History, Washington DC.

[27] Beentje, H. (2010) The Kew Plant Glossary an Illustrated Dictionary of Plant Terms. Kew Royal Botanic Gardens, Kew.

[28] Putz, F.E. and Holbrook, N.M. (1991) Biomechanical Studies in Vines. In: Putz, F.E. and Mooney, H.A., Eds., The Biology of Vines, Cambridge University Press, Cambridge, 73-97. 


\section{Appendix 1}

Table A1. Collection numbers and location of 16 investigated species in the family Menispermaceae in Taiwan.

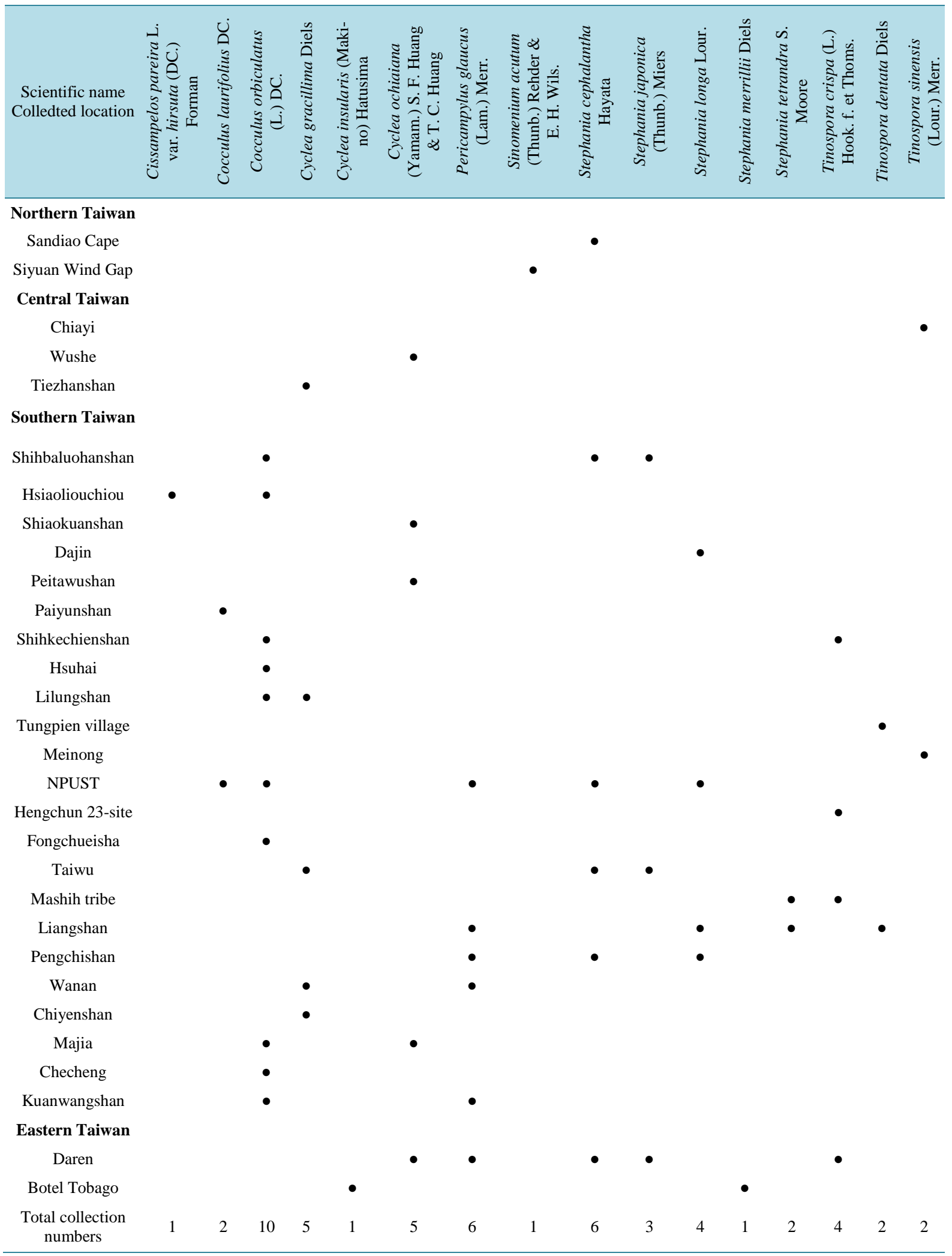




\section{Appendix 2. List of Morphological Characters and Definition of Cambial Variants}

Angyalossy et al. (2015) divided cambial variants into two types, namely, those that originate from a single cambium and those that originate from multiple cambia.

Single cambial variants are subdivided into six types:

1) Irregular conformation. The cambium exhibits regular activity, and the amount of xylem produced towards the inside of the stem exceeds the amount of phloem produced towards the outside of the stem; however, varying proportions of xylem and phloem are produced around the girth of the stem.

2) Interxylary phloem. The cambium typically produces xylem towards the inside of the stem and phloem towards the outside of the stem, but sometimes produces phloem that grows towards the inside and outside of the stem. This type of variant does not contain cambium (included cambium).

3) Arcs phloem. In some parts of the stem, the cambium produces less xylem than phloem. This type of variant contains included cambium.

4) Furrowed xylem. The xylem is furrowed by arcs and/or wedges, and this trait is termed wedge phloem This type of variant is derived from the part of the cambium that contains a relatively small amount of xylem and a relatively large amount of phloem; it is characterized by a regular gap between the xylem and phloem and irregular arrangements of the xylem and phloem.

5) Axial vascular elements in segments. Axial elements of the xylem and phloem are present in segments alternating with very wide xylem and phloem rays; this trait is termed "xylem in plates".

6) Dissected xylem. This type of variant is derived from the proliferation of non-lignified parenchyma.

Multiple cambial variants are subdivided into four types.

1) Successive cambia. New cambia arise successively through cell divisions in the external secondary vascular system. Each new cambium in the stem successively generates an inwardly pointing secondary xylem and an outwardly pointing secondary phloem. Cell divisions may involve i) pericyclic cell division, ii) cortex cell division, and iii) parenchyma cell division in the non-conducting phloem.

2) Compound stem. A compound stem is formed via multiple vascular cylinders in a single stem, which creates a cable-like structure. A compound stem may grow through primary or secondary growth; the latter involves the dedifferentiation of pericyclic parenchyma cells to form a new cambium, and this process produces external vascular cylinders without pith (Tamaio and Somner 2010).

3) Intraxylary phloem. This type of multiple cambial variant is derived from the formation of a cambium between the primary xylem and the pith.

4) External vascular cylinders. This type of multiple cambial variant is formed by i) neoformation of secondary vascular cylinders and ii) secondary growth of external primary vascular bundles. 